\title{
The Effect of Fund Shareholding on Agency Costs and Corporate Value
}

\author{
Menglou Zhang \\ School of Economics, Jinan University, Guangzhou, China \\ Email:1951416365@qq.com
}

How to cite this paper: Zhang, M. L. (2020). The Effect of Fund Shareholding on Agency Costs and Corporate Value. American Journal of Industrial and Business Management, 10, 1725-1738.

https://doi.org/10.4236/ajibm.2020.1011108

Received: October 8, 2020

Accepted: November 21, 2020

Published: November 24, 2020

Copyright $\odot 2020$ by author(s) and Scientific Research Publishing Inc. This work is licensed under the Creative Commons Attribution International License (CC BY 4.0).

http://creativecommons.org/licenses/by/4.0/ (c) (i) Open Access

\begin{abstract}
Whether funds can participate in corporate governance to reduce agency costs and enhance corporate value has always been a research hotspot in academia. This article uses all A-share listed companies held by funds from 2008 to 2018 to study the impact of fund holdings on agency costs and corporate value, and further discusses the regulatory effect of cash dividends on the relationship between fund holdings and agency costs and the intermediary effect of agency costs in the relationship between fund holdings and corporate value. The study found that: 1) The equity ownership by funds helps to suppress agency costs of listed companies, and cash dividends play a regulatory role; 2) The equity ownership by funds helps to increase the value of the enterprise, and agency costs play an intermediary role. Finally, it is proposed that the government should encourage the development of mutual funds and promote funds to participate in corporate governance; listed firms should establish the significance of cash dividends and pay attention to the role of cash dividends in corporate governance.
\end{abstract}

\section{Keywords}

Fund's Holding, Agency Costs, Cash Dividends, Corporate Value

\section{Introduction}

In order to establish a value investing concept and optimize the investor structure of the capital market, the China Securities Regulatory Commission (hereinafter referred to as the CSRC) proposed the "leapfrog" development of institutional investors as early as 2001. Mutual funds have the advantages of professional financial management, collective investment and capital scale. Different from the individual investor choosing to "free ride", in order to obtain excess returns, the funds may choose to actively participate in corporate governance, 
supervise the behavior of managers and restrain the encroachment effect of substantial shareholders.

But in reality, the investment behavior of funds does not seem to provide a basis for "Institutional Investor Activism". In 2015, the average annual turnover rate of mutual funds in China was 5.6 times. Although it declined in 2016 and 2017, it was still as high as 3.55 and 3.21 times. The high turnover rate of the funds has led to "Institutional retail" and short-term investment behavior (Bushee, 1998), and its trading behavior is contrary to the original intention of the CSRC's objective. In addition, by comparing the data of the fund's shareholding ratio and the largest shareholder's holding ratio in the annual report of listed companies in 2018, it is found that, on average, each listed company's fund holding ratio is about $3 \%$, while the largest shareholder's shareholding ratio is above $30 \%$, which may result in the fund's participation in corporate governance is not strong. Therefore, it is necessary to study whether the fund has the will and ability to participate in corporate governance and whether it can promote the development of listed companies.

Scholars have conducted research on the role of institutional investors participating in corporate governance and enhancing corporate value, but there are still controversies. The differences in the effects of institutional investors' participation in corporate governance may be due to the short sample length, underrepresented sample, and omission of important variables. As one of important methods of company profit distributions, cash dividend distribution is a return to shareholder's investment. It can be seen from Figure 1 that since the CSRC adopted using the dividend distribution policy as a condition for listed companies refinance in 2001, the average amount of cash dividend per share of A-share listed companies has gradually increased. However, the median pre-tax cash dividend per share is around 0.1 yuan. It means the cash dividends per share paying by most companies are lower than average. Combined with Figure 2 , it can be seen that although most companies implement cash dividend policies, the amount of cash dividends per share is not high. When the fund, as a company shareholder, cannot obtain sustained and stable returns, it may turn to the pursuit of capital gains from price differences by stock buying and selling. Cash dividends may be the missing variable that causes differences in the effects of fund participating in corporate governance.

This article's contribution: First, it studies the moderating effect of cash dividend on fund behaviors under the current background of cash dividend distribution policy in China, which supplements the deficiencies of previous studies. Studying the moderating effect of cash dividend on the relationship between fund shareholding and agency costs helps analyze which companies the fund can better play an active role in. Second, centering on the two types of agency costs, the mediating effect of agency costs in the relationship that fund shareholding influences on the value of the company is studied in detail, which verifies the activism of funds. 


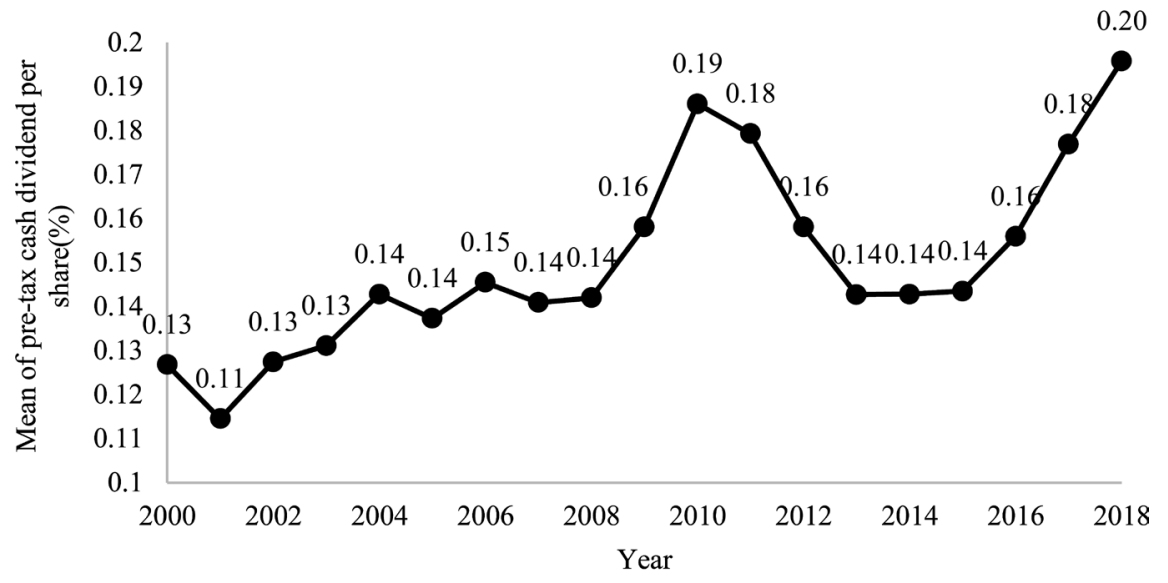

Figure 1. Mean of pre-tax cash dividends per share of A-share listed companies from 2000 to 2018.

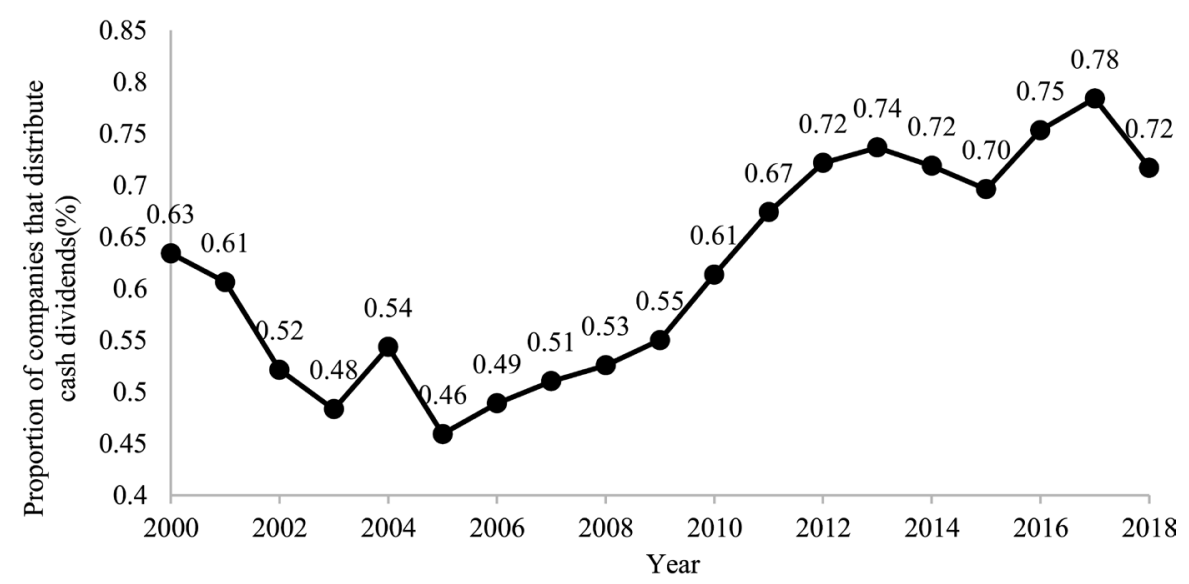

Figure 2. The proportion of A-share listed companies paying cash dividend from 2000 to 2018.

\section{Literature Review and Research Hypothesis}

The first type of principal-agent problem is between substantial shareholders and managers arising from the separation of enterprise ownership and management rights. According to Chinese "Listed Company Governance Standards" and "Securities Investment Fund Law", mutual funds can exercise shareholder rights in the selection of directors of listed companies, decision-making on major issues, supervision and management and incentives of operators. As an external supervision method, funds can negotiate privately with management and criticize publicly to restrict management's behavior. They can also use the behavior of "sell company stocks when company performance drops" to threaten companies to improve long-term performance (Edmans \& Manso, 2011).

The second type of principal-agent problem is the conflict between the substantial shareholders and minority shareholders. Compared with other institutional investors, the fund is more independent and has fewer existing or potential business relationships with companies, so it is less likely to collude with major shareholders; the fund, as the representative of minority tradable sharehold- 
ers, determines it protecting the rights of tradable shareholders, so the fund can play a supervisory role. Wu et al. (2016) support that institutional investors' ownership such as funds can reduce capital occupation by related parties. On the other hand, when the proportion of fund's shareholding is large, from the perspective of equity checks and balances, fund holdings can effectively restrain the controlling shareholder's behavior in seeking the private benefits of control (Li \& Zhang, 2011). Thus, this article proposes Hypothesis 1 and Hypothesis 2 :

H1: The higher the proportion of fund holdings, the lower the first type of agency costs.

$\mathrm{H} 2$ : The higher the fund holding ratio, the lower the second type of agency costs.

The ultimate goal of fund's participation in corporate governance is to obtain excess returns. Cash dividends are the source of continuous income for fund's shareholding. High and continuous cash dividends can improve the security and stability of fund shareholding and attract funds to make long-term and value investment. When the cash dividends of listed companies are small, the fund can only obtain income through the rise and fall of the stock market, which may cause the fund to carry out frequent operations in the market, concept speculation on stocks, and speculative trading. The high turnover rate of fund increases the average unit cost of the fund's participation in corporate governance. Therefore, only when fund implements a long-term value investment strategy will it participate in corporate governance and suppress the opportunistic behavior of management and controlling shareholders. Thus, this article proposes Hypothesis 3:

H3: A high cash dividend helps attract funds to participate in corporate governance, thereby reducing agency costs.

According to the effective supervision hypothesis of Institutional investors, funds can effectively supervise listed companies and enhance corporate performance value. Compared with individual investors, funds have advantages in capital, talent, information collection, and information analysis (Cornett, Marcus, Saunders, \& Tehranian, 2007; Siddharta \& William, 1997), and are more capable of overseeing the holding companies (Ferreira \& Matos, 2008). Compared with social security funds, qualified foreign institutional investors, securities firms and insurance companies, funds have a higher shareholding ratio, so they have higher incentives to participate in corporate governance and affect company value. Smith (1996) found that among the companies focused on by CalPERS, the performance of the companies that adopted CalPERS proposal can increase. Tang \& Song (2010) found that compared with other institutional investors, the fund not only chooses companies with better performance to invest, but also promotes companies' performance.

The two types of agency costs may play a partial mediating role between fund's shareholding and company performance. Institutional ownership can improve the efficiency of management incentives of listed companies, increase the sensitivity of management compensation to firm performance, improve the efficiency of man- 
agement decision-making, reduce management opportunism, and reduce the wealth embezzlement effect of major shareholders on listed companies, etc. Eventually it helps to promote company's value (Tang, Lin, \& Gao, 2015; Wang, 2013). Thus, this article proposes Hypothesis 4 and Hypothesis 5:

H4: Fund's shareholding can help increase corporate value.

H5: The two types of agency costs play the mediating effect in the relationship between fund shareholding and corporate value.

In order to verify the above hypotheses, this paper adopts linear regression models based on panel data. Furthermore, in order to ensure the credibility of the results, this article tests the robustness and endogenousness of the models. The specific model design and inspection methods are listed in section three. Finally, in order to increase the comprehensibility of the research hypothesis structure, the research framework is shown in Figure 3.

\section{Research Design}

\subsection{Sample Selection}

This article selects non-financial A-share listed companies in the Shanghai and Shenzhen stock exchanges from 2008 to 2018 as the initial observations. The sample data processing steps are as follows:

1) Remove the companies not held by fund;2) Remove the companies that were abnormally operated by ST, ${ }^{\star} \mathrm{ST}$, PT, etc. during the sample period; 3) Remove the companies whose listing years is less than 2 years; 4) Remove the companies with an asset-liability ratio greater than one; 5) Remove the companies that issue $\mathrm{B}$ shares or $\mathrm{H}$ shares; 6 ) Remove the companies with missing data.

In order to reduce the influence of extreme values, winsorize tail reduction method was used. That is to replace the values outside $1 \%-99 \%$ with the quantile values of $1 \%$ and $99 \%$ for the sample data of all continuous variables. Finally, 10,273 observations were obtained. All data come from Wind Financial Terminal and Cathay Pacific database. Wind Financial Terminal is provided by Wind Information Technology Co., Ltd. which is the main provider of China's financial information. Cathay Pacific database is provided by Shenzhen GTA Education Tech Ltd. Data from both Wind Financial Terminal and Cathay Pacific database are frequently quoted by Chinese media, in research reports, and in academic papers.

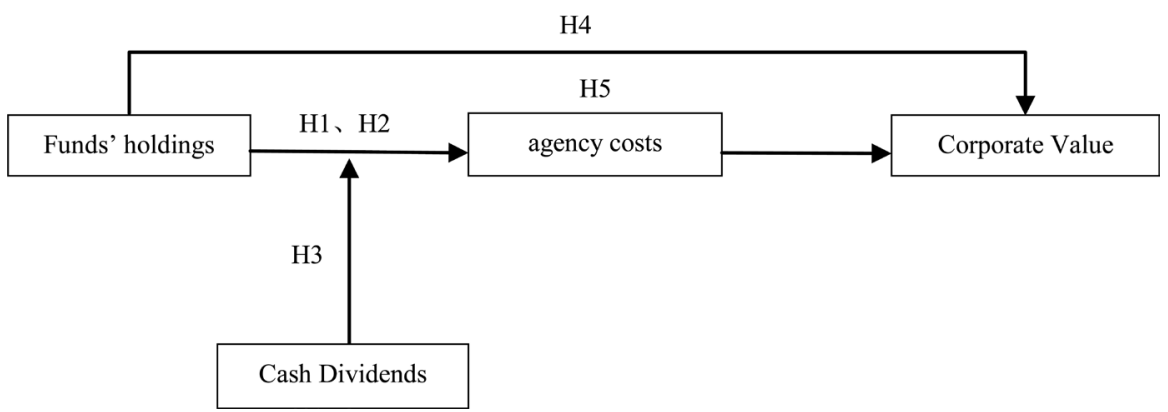

Figure 3. Research framework. 


\subsection{Variables}

First, there are three dependent variables, ROE (ROE) measures the value of the company, total asset turnover rate (asset_turn) measures the first type of agency cost, and the ratio of other receivables to total assets(occupy) measures the second type of agency costs.

Second, the independent variable is the proportion of shares held by the fund, which is the ratio of the number of shares held by the fund to the number of outstanding shares of the listed company.

Third, the moderating variable is cash dividend, which refers to cash dividend before tax per share.

Last, the control variables include the number of funds holding shares of the company (num), equity structure (share_1 and share2_10), nature of actual controller (state), the natural logarithm of the company's listing years (lnage), natural logarithm of the company's total assets (lnasset), asset-liability ratio (lev), and main business income growth rate (growth), whether the chairman and general manager is the same person (dual), the proportion of independent directors (lndep), the proportion of management-owned share ( $m_{-}$share), the natural logarithm of the total compensation of the top three executives (lnpay).

Among them, the equity structure includes the shareholding ratio of the largest shareholder (share_1) and the sum of shareholding ratios of the $2^{\text {nd }}$ to $10^{\text {th }}$ (share2_10); state (State-owned $=1$, otherwise $=0$ ); dual (the same person $=1$, otherwise $=0$ );

The variable descriptive statistics are shown in Table 1 . The average value of the funds' shareholding ratio is $7.723 \%$, and the median is $3.46 \%$. Each company is held by an average of 43.781 funds, and the standard deviation of numbers of funds holding shares of listed company is 56.519 . The mean value of shareholding ratio of the largest shareholder is $36.041 \%$, which is much higher than the average value of shareholding ratio of funds. This indicates the "One Big Share Alone" of the shares structure.

\subsection{Model Setting}

Equation (1) and Equation (2) are used to test the impact of fund's shareholding on agency costs, and the moderating effect of cash dividends in the relationship between the two; Equation (3) is used to test the impact of fund's shareholding on corporate value, and Equation (4) is used to test whether agency costs play medium roles between fund's shareholding and corporate value.

$$
\begin{aligned}
& \text { asset_turn }_{i, t+1}=\alpha+\beta_{1} \text { fund }_{i t}+\beta_{s} \text { Control variables }{ }_{i t}+u_{i}+\varepsilon_{i t} \\
& \text { occupy }_{i, t+1}=\alpha+\beta_{1} \text { fund }_{i t}+\beta_{s} \text { Control variables } i t+u_{i}+\varepsilon_{i t} \\
& R O E_{i, t+1}=\alpha+\beta_{1} \text { fund }_{i t}+\beta_{s} \text { Control variables }{ }_{i t}+u_{i}+\varepsilon_{i t} \\
& R O E_{i, t+1}=\alpha+\beta_{1} \text { fund }_{i t}+\beta_{2} \text { occupy }_{i, t+1}+\beta_{3} \text { asset_turn }_{i, t+1} \\
& +\beta_{s} \text { Control variables }{ }_{i t}+u_{i}+\varepsilon_{i t}
\end{aligned}
$$


Table 1. Variable descriptive statistics.

\begin{tabular}{|c|c|c|c|c|c|}
\hline Variable & Mean & SD & Median & Min & $\operatorname{Max}$ \\
\hline ROE (\%) & 8.730 & 8.587 & 8.106 & -25.677 & 34.497 \\
\hline occupy (\%) & 1.499 & 2.101 & 0.792 & 0.018 & 13.990 \\
\hline asset_turn & 0.671 & 0.458 & 0.566 & 0.074 & 2.686 \\
\hline DPS & 0.132 & 0.154 & 0.100 & 0.000 & 0.990 \\
\hline lnasset & 22.220 & 1.117 & 22.087 & 19.918 & 25.538 \\
\hline fund (\%) & 7.723 & 10.293 & 3.460 & 0.001 & 47.226 \\
\hline num & 43.781 & 56.519 & 24.000 & 1.000 & 1018.000 \\
\hline share_1 (\%) & 36.041 & 14.828 & 34.110 & 8.480 & 74.820 \\
\hline share2_10 (\%) & 21.955 & 12.417 & 20.620 & 2.080 & 53.470 \\
\hline lev (\%) & 41.827 & 19.627 & 41.265 & 5.579 & 87.119 \\
\hline indep & 0.370 & 0.053 & 0.333 & 0.000 & 0.800 \\
\hline dual & 0.238 & 0.426 & 0.000 & 0.000 & 1.000 \\
\hline m_share (\%) & 12.370 & 19.074 & 0.253 & 0.000 & 65.853 \\
\hline lnpay & 14.287 & 0.659 & 14.278 & 12.605 & 16.137 \\
\hline lnage & 2.089 & 0.673 & 2.124 & 0.739 & 3.206 \\
\hline growth (\%) & 23.137 & 44.153 & 14.359 & -52.240 & 319.647 \\
\hline state & 0.409 & 0.492 & 0.000 & 0.000 & 1.000 \\
\hline Observations: 1027 & & & & & \\
\hline
\end{tabular}

\section{Empirical Results and Analysis}

\subsection{The Impact of Fund's Shareholding on Agency Costs}

In the regression analysis of unbalanced panel data, the most appropriate model is selected from the fixed effects model, random effects model and mixed OLS regression model. Hausman test results support the use of fixed effects model for regression in Table 2. In order to reduce the influence of heteroscedasticity, the robust standard error of heteroscedasticity is used in regression with fixed effects model.

Table 2 shows the regression results of the relationship between the funds' shareholding ratio and agency costs. It can be seen from model (1) that, on average, with the proportion of shares held by funds increasing by $1 \%$, the total asset turnover rate increases by 0.001 . It means that funds' shareholding can help reduce management agency costs. It can be seen from the model (2) that, the regression coefficient of the funds' shareholding ratio is minus 0.007 , which is significant at the $5 \%$ level, that is, the higher the stock shareholding of funds, the lower the agency cost of substantial shareholders. It shows that, to a certain extent, the fund can reduce the behavior of substantial shareholders transferring benefits of listed companies through related transactions or embezzling. 
Table 2. The impact of funds' shareholding on agency costs.

\begin{tabular}{|c|c|c|}
\hline & (1) asset_turn & (2) occupy \\
\hline \multirow[t]{2}{*}{ fund } & $0.001^{\star * *}$ & $-0.007^{\star \star}$ \\
\hline & $(0.000)$ & $(0.003)$ \\
\hline \multirow[t]{2}{*}{ num } & $0.000^{\star * *}$ & 0.000 \\
\hline & $(0.000)$ & $(0.001)$ \\
\hline \multirow[t]{2}{*}{ lnasset } & $-0.154^{* * *}$ & 0.141 \\
\hline & $(0.013)$ & $(0.103)$ \\
\hline \multirow[t]{2}{*}{ lev } & $0.002^{* * *}$ & $0.012^{* * *}$ \\
\hline & $(0.000)$ & $(0.003)$ \\
\hline \multirow[t]{2}{*}{ growth } & $0.001^{\star * *}$ & $-0.001^{\star *}$ \\
\hline & $(0.000)$ & $(0.001)$ \\
\hline \multirow[t]{2}{*}{ indep } & 0.123 & 0.285 \\
\hline & $(0.089)$ & $(0.782)$ \\
\hline \multirow[t]{2}{*}{ dual } & 0.010 & 0.018 \\
\hline & $(0.012)$ & $(0.083)$ \\
\hline \multirow[t]{2}{*}{ m_share } & -0.000 & -0.005 \\
\hline & $(0.000)$ & $(0.003)$ \\
\hline \multirow[t]{2}{*}{ lnpay } & $0.025^{* *}$ & 0.002 \\
\hline & $(0.011)$ & $(0.076)$ \\
\hline \multirow[t]{2}{*}{ share_1 } & -0.001 & $-0.012^{\star *}$ \\
\hline & $(0.001)$ & $(0.005)$ \\
\hline \multirow[t]{2}{*}{ share2_10 } & -0.001 & $0.010^{\star \star}$ \\
\hline & $(0.001)$ & $(0.005)$ \\
\hline \multirow[t]{2}{*}{ lnage } & $0.051^{\star *}$ & 0.107 \\
\hline & $(0.021)$ & $(0.196)$ \\
\hline \multirow[t]{2}{*}{ state } & 0.012 & -0.054 \\
\hline & $(0.029)$ & $(0.380)$ \\
\hline \multirow[t]{2}{*}{ constant } & $3.484^{* * *}$ & -1.826 \\
\hline & $(0.287)$ & $(2.189)$ \\
\hline year & $\mathrm{Y}$ & $\mathrm{Y}$ \\
\hline fixed effect & $\mathrm{Y}$ & $\mathrm{Y}$ \\
\hline Obs & 10273 & 10273 \\
\hline R-squared & 0.187 & 0.017 \\
\hline Adjusted $\mathrm{R}^{2}$ & 0.185 & 0.015 \\
\hline F test & $25.77^{* * *}$ & $3.86^{* * *}$ \\
\hline Hausman test & $276.45^{\star * *}$ & $56.98^{\star * *}$ \\
\hline
\end{tabular}

Note: ${ }^{* *} p<0.01,{ }^{* *} p<0.05,{ }^{*} p<0.1$, Standard errors are in parenthesis. 


\subsection{The Moderating Effect of Cash Dividend}

Table 3 reports the moderating effect of cash dividend on the relationship between funds' holdings and agency costs. Based on the median of cash dividend, the samples are divided into a low cash dividend distribution sample group and a high distribution sample group. It can be seen from Table 3 that in the observations with low cash dividends, the coefficient of the influence of fund holdings on agency costs is not significant. It means the willingness of funds to participate in corporate governance has declined. In column (3), the regression coefficient of funds' shareholding to total asset turnover is positive which is significant at the $1 \%$ level; In column (4), the regression coefficient of funds' shareholding to other receivables ratio is negative, which is significant at the $5 \%$ level. In summary, in the sample with high cash dividends, as the funds' shareholding increases by $1 \%$, the agency costs will reduce by 0.002 and 0.009 respectively. These results show that cash dividend as an adjustment mechanism, high-level cash dividend distribution can indeed attract funds to make long-term investments and value investments, participate in corporate governance, and supervise managers and restrain substantial shareholders. Hypothesis 3 has been verified.

\subsection{The Influence of Funds' Shareholding on Corporate Value and the Intermediary Role of Agency Costs}

From model (1) in Table 4, it is reported that stock shareholding of funds is positively relevant to the performance of listed companies in the next period. On average, for every $1 \%$ increase in the shareholding ratio of the fund, the performance of companies in the next period will increase by 0.112 , indicating that the fund has the ability to create value. Hypothesis 4 has been verified.

After adding the intermediary variables, the coefficient of stock shareholding of funds is still positive and significant. The coefficient of total asset turnover is positive and significant at the $1 \%$ level. The coefficient of other accounts receivable ratio is negative, which is significant at the $5 \%$ level. Overall, it can be seen that funds' shareholding has a positive impact on corporate value, and agency costs play a partial intermediary effect. Hypothesis 5 is verified.

\subsection{Robustness Test}

\subsubsection{Test of the Adjustment Effect}

To avoid that the test results are not representative brought by different grouping methods. In the robustness test, another grouping method is used to test the moderating effect of cash dividend. The significance of the regression coefficients of fund's shareholding has increased respectively in model (3) and model (4) in Table 5, supporting the above results.

\subsubsection{The Test of the Mediation Effect}

Use earnings per share as a substitute variable for company value to test the intermediary effect of agency costs. The results are shown in Table 6. After adding agency costs as intermediary variables, the coefficient of total asset turnover ratio 
Table 3. The impact of funds' shareholding on agency costs.

\begin{tabular}{|c|c|c|c|c|}
\hline & \multicolumn{2}{|c|}{ low cash dividend distribution } & \multicolumn{2}{|c|}{ high cash dividend distribution } \\
\hline & (1) asset_turn & (2) occupy & (3) asset_turn & (4) occupy \\
\hline \multirow[t]{2}{*}{ fund } & 0.000 & -0.007 & $0.002^{\star \star \star}$ & $-0.009^{\star *}$ \\
\hline & $(0.001)$ & $(0.006)$ & $(0.001)$ & $(0.004)$ \\
\hline \multirow[t]{2}{*}{ num } & 0.000 & 0.001 & 0.000 & 0.001 \\
\hline & $(0.000)$ & $(0.002)$ & $(0.000)$ & $(0.001)$ \\
\hline \multirow[t]{2}{*}{ lnasset } & $-0.126^{\star * *}$ & 0.190 & $-0.177^{\star * *}$ & 0.022 \\
\hline & $(0.018)$ & $(0.161)$ & $(0.019)$ & $(0.149)$ \\
\hline \multirow[t]{2}{*}{ lev } & $0.002^{* * *}$ & $0.012^{* *}$ & $0.003^{* * *}$ & $0.011^{* * *}$ \\
\hline & $(0.001)$ & $(0.005)$ & $(0.001)$ & $(0.004)$ \\
\hline \multirow[t]{2}{*}{ growth } & $0.001^{* * *}$ & $-0.002^{\star}$ & $0.001^{* * *}$ & -0.001 \\
\hline & $(0.000)$ & $(0.001)$ & $(0.000)$ & $(0.001)$ \\
\hline \multirow[t]{2}{*}{ indep } & 0.154 & -0.561 & 0.100 & 0.762 \\
\hline & $(0.126)$ & $(1.435)$ & $(0.111)$ & $(0.867)$ \\
\hline \multirow[t]{2}{*}{ dual } & 0.015 & -0.050 & -0.014 & 0.052 \\
\hline & $(0.016)$ & $(0.142)$ & $(0.019)$ & $(0.096)$ \\
\hline \multirow[t]{2}{*}{ m_share } & -0.000 & 0.000 & 0.001 & -0.006 \\
\hline & $(0.001)$ & $(0.005)$ & $(0.001)$ & $(0.005)$ \\
\hline \multirow[t]{2}{*}{ lnpay } & 0.014 & 0.049 & $0.034^{* * *}$ & 0.097 \\
\hline & $(0.014)$ & $(0.149)$ & $(0.013)$ & $(0.092)$ \\
\hline \multirow[t]{2}{*}{ share_1 } & -0.001 & -0.012 & -0.000 & -0.006 \\
\hline & $(0.001)$ & $(0.009)$ & $(0.001)$ & $(0.007)$ \\
\hline \multirow[t]{2}{*}{ share2_10 } & $-0.002^{\star \star}$ & 0.008 & 0.000 & $0.014^{\star *}$ \\
\hline & $(0.001)$ & $(0.008)$ & $(0.001)$ & $(0.006)$ \\
\hline \multirow[t]{2}{*}{ lnage } & 0.028 & 0.257 & $0.076^{\star * *}$ & 0.139 \\
\hline & $(0.030)$ & $(0.338)$ & $(0.026)$ & $(0.245)$ \\
\hline \multirow[t]{2}{*}{ state } & -0.001 & 0.080 & 0.033 & -0.351 \\
\hline & $(0.039)$ & $(0.599)$ & $(0.030)$ & $(0.524)$ \\
\hline \multirow[t]{2}{*}{ constant } & $3.059^{* * *}$ & -3.713 & $3.842^{* * *}$ & -1.675 \\
\hline & $(0.427)$ & $(3.790)$ & $(0.434)$ & $(3.151)$ \\
\hline year & $\mathrm{Y}$ & $\mathrm{Y}$ & $\mathrm{Y}$ & $\mathrm{Y}$ \\
\hline fixed effect & $\mathrm{Y}$ & $\mathrm{Y}$ & $\mathrm{Y}$ & $\mathrm{Y}$ \\
\hline Obs & 5137 & 5137 & 5136 & 5136 \\
\hline R-squared & 0.154 & 0.024 & 0.218 & 0.018 \\
\hline Adjusted $\mathrm{R}^{2}$ & 0.150 & 0.020 & 0.214 & 0.013 \\
\hline $\mathrm{F}$ test & $12.25^{\star * \star}$ & $2.27^{\star * *}$ & $14.22^{\star * *}$ & $1.77^{\star \star}$ \\
\hline Hausman test & $120.78^{* * *}$ & $36.24^{\star *}$ & $71.57^{\star \star *}$ & $35.05^{\star *}$ \\
\hline
\end{tabular}

Note: ${ }^{* *} p<0.01,{ }^{* *} p<0.05,{ }^{*} p<0.1$, Standard errors are in parenthesis. 
Table 4. The influence of funds' shareholding on company value and the mediating effect of agency costs.

\begin{tabular}{|c|c|c|}
\hline & (1) ROE & (2) ROE \\
\hline \multirow[t]{2}{*}{ fund } & $0.112^{\star * *}$ & $0.099^{* * *}$ \\
\hline & $(0.011)$ & $(0.011)$ \\
\hline \multirow[t]{2}{*}{ asset_turn } & & $9.009^{* * *}$ \\
\hline & & $(0.768)$ \\
\hline \multirow[t]{2}{*}{ occupy } & & $-0.162^{* *}$ \\
\hline & & $(0.068)$ \\
\hline \multirow[t]{2}{*}{ num } & $0.018^{* * *}$ & $0.016^{* * *}$ \\
\hline & $(0.003)$ & $(0.002)$ \\
\hline \multirow[t]{2}{*}{ lnasset } & $-4.519^{* * *}$ & $-3.106^{* * *}$ \\
\hline & $(0.374)$ & $(0.387)$ \\
\hline \multirow[t]{2}{*}{ lev } & $0.075^{* * *}$ & $0.057^{\star * *}$ \\
\hline & $(0.013)$ & $(0.013)$ \\
\hline \multirow[t]{2}{*}{ growth } & $0.024^{* * *}$ & $0.016^{* * *}$ \\
\hline & $(0.002)$ & $(0.002)$ \\
\hline \multirow[t]{2}{*}{ indep } & 3.014 & 1.951 \\
\hline & $(2.581)$ & $(2.527)$ \\
\hline \multirow[t]{2}{*}{ dual } & 0.383 & 0.294 \\
\hline & $(0.351)$ & $(0.351)$ \\
\hline \multirow[t]{2}{*}{ m_share } & $0.045^{\star *}$ & $0.045^{\star *}$ \\
\hline & $(0.019)$ & $(0.019)$ \\
\hline \multirow[t]{2}{*}{ lnpay } & $1.770^{\star * *}$ & $1.545^{\star * *}$ \\
\hline & $(0.309)$ & $(0.303)$ \\
\hline \multirow[t]{2}{*}{ share_1 } & $0.124^{\star * *}$ & $0.128^{\star * *}$ \\
\hline & $(0.023)$ & $(0.022)$ \\
\hline \multirow[t]{2}{*}{ share2_10 } & $0.094^{\star * *}$ & $0.103^{* * *}$ \\
\hline & $(0.018)$ & $(0.017)$ \\
\hline \multirow[t]{2}{*}{ lnage } & $1.520^{* *}$ & 1.078 \\
\hline & $(0.663)$ & $(0.655)$ \\
\hline \multirow[t]{2}{*}{ state } & -1.747 & $-1.868^{*}$ \\
\hline & $(1.064)$ & $(1.017)$ \\
\hline \multirow[t]{2}{*}{ constant } & $68.390^{* * *}$ & $36.709^{* * *}$ \\
\hline & $(8.338)$ & $(8.784)$ \\
\hline year & $\mathrm{Y}$ & $\mathrm{Y}$ \\
\hline fixed effect & $\mathrm{Y}$ & $\mathrm{Y}$ \\
\hline Observations & 10273 & 10273 \\
\hline R-squared & 0.173 & 0.223 \\
\hline Adjusted $\mathrm{R}^{2}$ & 0.171 & 0.222 \\
\hline $\mathrm{F}$ test & $39.27^{* * *}$ & $42.10^{* * *}$ \\
\hline Hausman test & $512.91^{\star * *}$ & $802.42^{\star * *}$ \\
\hline
\end{tabular}

Note: ${ }^{* *} p<0.01,{ }^{* *} p<0.05,{ }^{*} p<0.1$, Standard errors are in parenthesis. 
Table 5. Robustness test of moderating effect of cash dividend.

\begin{tabular}{ccccc}
\hline & \multicolumn{2}{c}{$\begin{array}{c}\text { Sample with cash dividends less than } \\
\text { the sample mean }\end{array}$} & $\begin{array}{c}\text { Sample with cash dividends greater } \\
\text { than the sample mean }\end{array}$ \\
\cline { 2 - 5 } & (1) asset_turn & (2) occupy & (3) asset_turn & (4) occupy \\
\hline fund & $0.001^{*}$ & $-0.006^{*}$ & $0.002^{* * *}$ & $-0.006^{* * *}$ \\
& $(0.000)$ & $(0.003)$ & $(0.001)$ & $(0.002)$ \\
control variables & $\mathrm{Y}$ & $\mathrm{Y}$ & $\mathrm{Y}$ & $\mathrm{Y}$ \\
Observations & 7076 & 7076 & 3197 & 3197 \\
R-squared & 0.167 & 0.022 & 0.249 & 0.014 \\
\hline
\end{tabular}

Note: ${ }^{* *} p<0.01,{ }^{* *} p<0.05,{ }^{*} p<0.1$, Standard errors are in parenthesis.

Table 6. The robustness test with EPS as a substitute variable.

\begin{tabular}{ccc}
\hline & $(1) \mathrm{EPS}$ & $(2) \mathrm{EPS}$ \\
\hline fund & $0.004^{* * *}$ & $0.004^{* * *}$ \\
& $(0.001)$ & $(0.001)$ \\
asset_turn & & $0.339^{* * *}$ \\
& & $(0.034)$ \\
occupy & & $-0.008^{* * *}$ \\
& & $(0.003)$ \\
control variables & $\mathrm{Y}$ & $\mathrm{Y}$ \\
Observations & 10273 & 10273 \\
R-squared & 0.121 & 0.158
\end{tabular}

Note: ${ }^{* *} p<0.01,{ }^{* *} p<0.05,{ }^{*} p<0.1$, Standard errors are in parenthesis.

is significantly positively, and other receivables ratio is significantly negatively correlated with earnings per share. The coefficient of fund's shareholding is still significant at the $1 \%$ level, indicating that agency costs are the partial mediation.

\subsection{Endogenous Test}

Mutual funds may select stocks based on the future value of company. It is necessary to conduct an endogenous test on the relationship between funds' shareholding and corporate value. Dai, Liu \& Yang (2013) believe that the endogenous nature between funds' shareholding and agency costs is weak, and it is difficult for funds to purchase or sell stock based on agency costs that exist in a firm. Therefore, this article mainly tests the endogenousness between funds' shareholding and corporate value. By using the stock turnover rate of listed companies and the lagged funds' shareholding ratio as instrumental variables of the funds' shareholding ratio, the results in Table 7 show that after controlling the endogenous problems, funds' shareholding still has a positive impact on firm value. 
Table 7. Two stage least square.

\begin{tabular}{ccc}
\hline & (1) First stage regress & (2) Second stage regress \\
\cline { 2 - 3 } fund & & ROE \\
fund & & $0.254^{* * *}$ \\
L.fund & $0.257^{* * *}$ & \\
& $(0.016)$ & \\
turnover & $-0.001^{* * *}$ & \\
& $(0.000)$ & $\mathrm{Y}$ \\
control variables & $\mathrm{Y}$ & 7287 \\
Observations & 7287 & 0.156 \\
R-square & 0.426 & \\
F test & $72.94^{* * *}$ & $7870.99^{* * *}$ \\
Wald chi2(21) & & \\
\hline
\end{tabular}

Note: ${ }^{* *} p<0.01,{ }^{* *} p<0.05,{ }^{*} p<0.1$, Standard errors are in parenthesis.

\section{Research Conclusions and Recommendations}

By using the data of A-share listed companies from 2008 to 2018, it studies the impact of funds' shareholding on corporate agency costs and corporate value. Further, it examines the intermediary effect of agency costs on the relationship between funds' holding and corporate value, and the moderating effect of cash dividends in the influence of funds' shareholding on agency costs. The research found that: 1) The increase in the proportion of funds' shareholding inhibited the two types of agency costs in listed companies; 2) Cash dividend played a moderating role in the relationship between agency costs and funds' shareholding. In companies with high cash dividend distribution, mutual funds are more willing to participate in corporate governance; 3) Funds' shareholdings can promote the increase of company value; 4) By studying the transmission mechanism of how funds promote company value, it is found that funds can increase company value by restraining two types of agency costs.

The research results show that funds' shareholding can improve the performance of listed companies through implementing effective supervision on the management and substantial shareholders of listed companies. Based on this, the following suggestions are made: 1) In order to optimize the investor structure of Chinese capital market, the development of mutual funds should continue to be encouraged and supported. 2) Fund should realize shareholder activism can obtain higher returns than the passive attitude, and actively participate in governance of the companies it held. 3) Listed companies should establish a correct concept of cash dividends distribution and attract funds to implement value investing.

Because agency costs of a company are difficult to measure, this article uses 
the ratio of other receivables to total assets and the total asset turnover rate to indirectly measure the two types of agency costs. It may not be a comprehensive measure of the encroachment effect of managers and major shareholders. Therefore, it may be necessary to find more suitable substitute variables of agency costs for further research.

\section{Conflicts of Interest}

The author declares no conflicts of interest regarding the publication of this paper.

\section{References}

Bushee, B. J. (1998). The Influence of Institutional Investors on Myopic R\&D Investment Behavior. The Accounting Review, 73, 305-333.

Cornett, M. M., Marcus, A. J., Saunders, A., \& Tehranian, H. (2007). The Impact of Institutional Ownership on Corporate Operating Performance. Journal of Banking \& Finance, 31, 1771-1794. https://doi.org/10.1016/j.jbankfin.2006.08.006

Dai, J. E., Liu, K., \& Yang, Z. Q. (2013). Empirical Study on Relationship between Institutional Shareholding and Corporate Governance: From Perspective of Agency Cost. Technology Economics, 32, 109-116.

Edmans, A., \& Manso, G. (2011). Governance through Trading and Intervention: A Theory of Multiple Blockholders. Review of Financial Studies, 24, 2395-2428. https://doi.org/10.1093/rfs/hhq145

Ferreira, M. A., \& Matos, P. (2008). The Colors of Investors' Money: The Role of Institutional Investors around the World. Journal of Financial Economics, 88, 499-533. https://doi.org/10.1016/j.jfineco.2007.07.003

Li, Z. H., \& Zhang, D. X. (2011). Fund Shareholding and Corporate Performance: A Study of a Unique Angle from the Second-Largest Shareholder Shareholding. Shanghai Journal of Economics, 70-80.

Siddharta, U., \& William, M. C. (1997). Institutional Ownership, Differential Pre-Disclosure Precision and Trading Volume at Announcement Dates. Journal of Accounting \& Economics, 24, 129-150. https://doi.org/10.1016/S0165-4101(98)00003-2

Smith, M. P. (1996). Shareholder Activism by Institutional Investors: Evidence for CalPERS. The Journal of Finance, 51, 227-252. https://doi.org/10.1111/j.1540-6261.1996.tb05208.x

Tang, Y. J., \& Song, Y. Y. (2010). Value-Selection VS Value-Creation: Evidence from Inatitutional Investors in the Chinese Market. China Economics Quarterly, 9, 223-246.

Tang, S. L., Lin, S. Y., \& Gao, L. L. (2015). Institutional Ownership, Free Cash and Investment Efficiency. Management Review, 27, 24-35.

Wu, X. C., Zhang, J., \& Hu, Z. Y. (2016). Heterogeneity of Institutional Investors, Features of Ultimate Controllers and Large Shareholders' Tunneling: Based on the Related-Party Transactions. Foreign Economics \& Management, 38, 3-20.

Wang, X. (2013). The Realization of Insititutional Shareholder Activism-An Angle from the Mediating Effect of Agency Cost. Dong Yue Tribune, 34, 164-168. 